\title{
Cytosolic Phospholipase A2 Delta
}

National Cancer Institute

\section{Source}

National Cancer Institute. Cytosolic Phospholipase A2 Delta. NCI Thesaurus. Code C38596.

Cytosolic phospholipase A2 delta ( $818 \mathrm{aa}, \sim 92 \mathrm{kDa}$ ) is encoded by the human PLA2G4D gene. This protein plays a role in phospholipid metabolism. 